\title{
STRATEGI PENGEMBANGAN AGRIBISNIS PADI ORGANIK PADA KOMUNITAS PETANI ORGANIK ASTORAHAYU DESA ASTOMULYO, KECAMATAN PUNGGUR, LAMPUNG TENGAH
}

\author{
Aan Andika*, Khairul Amri, Zulkarnain \\ Program Studi Agribisnis, Sekolah Tinggi Ilmu Pertanian (STIPER) Dharma Wacana Metro \\ Jl. Kenanga No.3, Mulyojati, Metro Barat, Kota Metro, Lampung 34152 \\ *Corresponding author: stiperdwmetro@gmail.com
}

\begin{abstract}
Public demand for rice food has increased while the availability of organic rice is still limited. So that organic rice farming is more promising to be developed. This study aims to determine the agribusiness developing strategy for organic rice in the Astorahayu Organic Farmers Community, Astomulyo Village, Punggur District, Central Lampung Regency. The analytical methods used are IFE, EFE, IE, Analysis of Strengths, Weaknesses, Opportunities, Threats (SWOT), and Analytical Hierarchy Process (AHP). The analysis results showed that the IFE matrix's weight is 2.70, and the EFE matrix is 2.35. The IE matrix is in a hold and maintains position with a market penetration strategy and product development. SWOT analysis produces 12 alternative strategies that can be applied for organic rice expansion. The AHP results show that the level of criteria are the main priority in developing organic rice are increasing marketing and institutionalization with a weight of 0.301. At the objective level, the primary importance of developing the organic rice agribusiness system is expanding the production capacity of organic rice with a weight of 0.508. At the actor level, the farmer in the Astorahayu organic paddy community with a weight of 0.435. The primary priority alternative strategy is to improve the skills of organic rice cultivation by utilizing the cooperation of the organic farming community members to increase productivity with a weight of 0.183 .
\end{abstract}

Keywords: organic rice, SWOT, AHP, development strategy

\begin{abstract}
Abstrak: Penelitian ini bertujuan untuk mengetahui strategi pengembangan agribisnis padi organik di Komunitas Petani Organik Astorahayu, Desa Astomulyo, Kecamatan Punggur, Kabupaten Lampung Tengah. Lokasi ini dipilih karena merupakan satusatunya di Lampung Tengah yang telah memiliki sertifikasi resmi pangan organik dari INOFICE. Jumlah sampel dalam penelitian sebanyak 19 responden, terdiri dari 13 petani organik dan 6 responden ahli yang dipilih secara sensus dan purposive sampling. Metode analisis yang digunakan adalah Analisis Internal Factor Evaluation (IFE), Analisis External Factor Evaluation (EFE), Analisis Internal External (IE), Analisis Strengths, Weaknesses, Opportunities and Threats (SWOT) dan Analytical Hierarchy Process (AHP). Hasil Analisis menunjukkan bahwa, total bobot matriks IFE 2,70 dan matriks EFE 2,35 sehingga matriks IE usaha padi organik Astorahayu berada di posisi hold and maintain (pertahankan dan pelihara) dengan strategi penetrasi pasar dan pengembangan produk. Analisis SWOT menghasilkan 12 alternatif strategi yang dapat diterapkan untuk mengembangkan padi organik. Hasil AHP menunjukkan bahwa level kriteria yang menjadi prioritas utama dalam tercapainya fokus pengembangan padi organik adalah peningkatan pemasaran dan kelembagaan dengan bobot 0,301. Pada level tujuan, prioritas utama dalam strategi pengembangan agribisnis padi organik yaitu meningkatkan kemampuan produksi padi organik dengan bobot 0,508. Pada level aktor, yang menduduki peringkat pertama yaitu petani komunitas padi organik Astorahayu dengan bobot 0,435. Alternatif strategi prioritas
\end{abstract}


utama yang didapat dari hasil sintesis adalah meningkatkan keterampilan budidaya padi organik dengan memanfaatkan kerjasama anggota komunitas petani organik guna meningkatkan produktifitas dengan bobot 0,183.

Kata kunci: padi organik, SWOT, AHP, strategi pengembangan

\section{PENDAHULUAN}

Republik Indonesia adalah negeri agraris dan tata kelola pembangunan di sektor agriculture menjadi prioritas utama dalam peningkatan ekonomi, baik secara mikro maupun makro (Sucihatiningsih dan Waridin, 2010). Pertanian menjadi jantung yang memiliki peran sangat vital dalam perekonomian Indonesia, salah satunya yaitu menjadi penggerak sekaligus supplier berbagai bahan kebutuhan pokok bagi mayoritas masyarakat Indonesia. Pangan adalah kebutuhan yang fundamental dan primer bagi suatu bangsa termasuk Indonesia, oleh karena itu pangan disebut sebagai kebutuhan hak asasi setiap manusia. Pilar penting sekaligus kekuatan suatu negara adalah ketahanan pangan. Pertanian organik di Indonesia mulai ramai dimulai pada awal 1980 -an, terlihat dari pertambahan luas lahan pertanian organik yang terus meningkat (Jumna, 2015). Pemanfaatan lahan di Indonesia baru 126.014 hektar yang digunakan untuk budidaya pertanian organik, maka masih diperlukan berbagai upaya khusus serta kegiatan yang terintegrasi secara sinergis agar dapat menjadikan Indonesia sebagai salah satu produsen pangan organik dunia (Research Institute of Organik Agriculture (FIBL), 2018).

Seiring berjalannya waktu jumlah penduduk semakin meningkat, menuntut permintaan dan ketersediaan pangan bermutu dalam jumlah yang cukup. Di masa kini petani masih sangat tergantung dengan pupuk kimia, sehingga dalam pemakaiannya seringkali berlebihan. Hal ini merupakan respon daripada kebijakan subsidi yang diberikan oleh pemerintah (Balitbangtan, 2010).

Pemakaian berlebihan dan penggunaan jangka panjang pupuk kimia sintetis akan mengurangi kualitas tanah dan membuat tanah semakin miskin akan unsur hara, sehingga hasil produksi akan semakin turun. Pengaplikasian input kimia sintesis akan memengaruhi kualitas pangan yang dihasilkan. Selain itu, produkproduk hasil pertanian akan tercampur dengan bahan-bahan yang berbahaya, sehingga dapat merusak sistem dalam tubuh manusia (Lestari,
2009). Banyaknya bahaya dan dampak negatif dari bahan kimia menciptakan kesadaran baru dan sitem pertanian organik mulai dianggap penting oleh para ahli (Rai, 2018). Sistem budidaya padi organik dan berkelanjutan mempunyai potensi untuk menjaga kelestarian dan kesehatan alam. Pertanian organik meminimalisir bahkan menghilangkan beban lingkungan, namun pada masa yang bersamaan dapat meningkatkan pendapatan usahatani (Aminah, 2017).

Bertambahnya pengetahuan dan kesadaran tentang bahaya terhadap kesehatan dan lingkungan menimbulkan peralihan budidaya dari sistem konvensional menuju sistem budidaya organik. Komoditas padi merupakan bagian dari pangan yang penting dalam pembangunan sektor pertanian. Padi merupakan salah satu komoditas utama yang dibudidayakan petani Indonesia, menghasilkan beras sebagai makanan pokok masyarakat. Masyarakat dunia pada umumnya dan khusunya di Indonesia biasa memakan beras anorganik, namun saat ini secara perlahan sudah beralih untuk lebih mengkonsumsi beras organik. Pangan yang aman, sehat dan bergizi tinggi dapat dihasikan dengan teknologi sistem pertanian organik.

Provinsi Lampung memiliki potensi yang cukup besar untuk menjadi pusat beras organik, karena merupakan provinsi yang mengusahakan penanaman padi organik di Indonesia. Di Provinsi Lampung, yaitu Kabupaten Lampung Tengah memiliki beberapa wilayah yang memproduksi padi organik salah satu nya di Desa Astomulyo Kecamatan Punggur. Data terbaru 2019 menyebutkan bahwa luas lahan pertanian padi organik di Astomulyo, Punggur mencapai 5 hektar, yang mampu memproduksi padi organik per tahun sebanyak 26 ton beras putih, 6 ton beras merah dan 2 ton beras hitam. Wilayah Lampung Tengah senantiasa meningkatkan produktivitas agar dapat memenuhi permintaan masyarakat akan beras organik. Permintaan terhadap komoditas pangan beras organik terus meningkat, di sisi 
lain ketersediaan padi organik masih sedikit atau sangat terbatas. Dengan demikian usahatani padi organik lebih menjanjikan untuk dikembangkan. Faktor pendorong berkembangnya pertanian organik ialah pesatnya permintaan masyarakat terhadap hasil pertanian organik, khususnya dimulai dari negara-negara maju seperti Amerika dan Eropa, yang juga merupakan negara yang melahirkan dan mengembangkan pertanian organik (Jamison dan Perkins, 2010).

Permasalahan dalam pertanian organik adalah seperti banyak petani belum menerapkan pertanian organik, minimnya dukungan kebijakan pemerintah, permintaan semakin tinggi namun produksi masih rendah, terbatasnya jaringan, minimnya kegiatan promosi serta masalah kelembagaan yang cukup kompleks menjadikan pengembangan padi organik cukup lambat, sehingga perlu adanya strategi khusus untuk memecahkan masalah tersebut.

Berdasarkan uraian tersebut, maka tujuan penelitian ini adalah untuk menganalisis strategi pengembangan agribisnis padi organik pada Komunitas Petani Organik Astorahayu, Desa Astomulyo, Kecamatan Punggur, Kabupaten Lampung Tengah.

\section{METODE PENELITIAN}

Penelitian ini dilakukan di Desa Astomulyo yang berlokasi di Kecamatan Punggur, Kabupaten Lampung Tengah, Provinsi Lampung. Penelitian ini dilaksanakan pada bulan Oktober 2019. Metode penelitian ini menggunakan data primer dan data skunder. Data primer ialah data yang diperoleh dan dikumpulkan secara langsung untuk menjawab masalah atau tujuan penelitian yang dilakukan dengan cara observasi, wawancara, diskusi dan kuesioner, yang telah dipersiapkan sebelumnya. Data sekunder adalah data yang diperoleh dan dikumpulkan dari pihak lain (pihak eksternal). Data sekunder diperoleh dari kumpulan data yang dimiliki pihak perusahaan, kajian pustaka, dan instansi terkait (BPS, BPP, Dinas Pertanian) dan data-data lain yang diperlukan untuk menunjang penelitian.

Metode penentuan sampel yang dipakai dalam penelitian ini adalah nonprobability sampling yakni dengan sampling jenuh (sensus) yaitu metode penarikan sampel apabila semua anggota populasi dijadikan sebagai sampel. Metode ini sering digunakan apabila jumlah populasi kecil, kurang dari 30 orang. Dalam penelitian ini responden yang akan diambil adalah sebanyak 19 orang, yakni terdiri dari 13 orang petani padi organik Desa Astomulyo, Kecamatan Punggur, Kabupaten Lampung Tengah yang merupakan populasi dan ditambah 6 orang responden ahli padi organik yang bukan bagian dari populasi yaitu ketua PERHIPTANI Provinsi Lampung, Dinas Pertanian Provinsi Lampung, Dinas Pertanian Kabupaten Lampung Tengah, Penyuluh Pertanian Kecamatan Punggur, Pihak Mitra dan Petani Komunitas Internal Control System.

Metode analisis yang digunakan dalam penelitian ini yaitu analisis SWOT. Analisis SWOT menghasilkan berbagai alternatif strategi yang dapat memaksimumkan kekuatan dan peluang serta meminimumkan kelemahan dan ancaman yang ada, sehingga strategi pengembangan dapat diketahui untuk diterapkan pada daerah penelitian. Tahapan dalam analisis SWOT dimulai dengan pengumpulan informasi mengenai perkembangan sistem agribisnis di Desa Astomulyo Kecamatan Punggur, kemudian mengidentifikasi faktor-faktor yang dapat memengaruhi pengembangan sistem agribisnis padi organik di Desa Astomulyo. Dari faktorfaktor yang diperoleh melalui wawancara responden maka dapat ditentukan faktor-faktor strategis. Kemudian mengklasifikasikan faktorfaktor strategis tersebut ke dalam faktor eksternal dan faktor internal. Faktor eksternal adalah faktor yang tidak dapat dikendalikan oleh petani. Faktor internal adalah faktor yang dapat dikendalikan oleh petani.

Tahap selanjutnya adalah melakukan scoring pada masing-masing faktor dengan memberikan nilai 4 (sangat baik), nilai 3 (baik), nilai 2 (cukup baik) dan nilai 1 (tidak baik) didasarkan kepada pengaruh faktor tersebut terhadap kondisi kelompok tani atau organisasi yang berkaitan. Pemberian nilai skor pada faktor peluang (Opportunity) bersifat positif, yakni diberi skor +1 untuk peluang yang kecil dan diberi +4 untuk peluang yang besar. Pemberian nilai skor pada ancaman (Threat) adalah kebalikannya. Faktor yang termasuk kategori kekuatan (Strength) diberi nilai +1 (sangat buruk) sampai dengan +4 (sangat baik), dan untuk faktor dalam kategori kelemahan 
(Weakness) ialah kebalikannya. Selanjutnya faktor dibagi menjadi empat skoring, yaitu pada faktor internal 1 dan 2 merupakan kelemahan serta 3 dan 4 merupakan kekuatan. Pada faktor eksternal, 1 dan 2 merupakan ancaman sedangkan 3 dan 4 merupakan peluang.

Metode Analytical Hierarchy Process merupakan sebuah metode analisis pengambilan keputusan berhirarki yang dikembangkan oleh seorang ahli Matematika Thomas L Saaty pada tahun 1993. Metode ini adalah sebuah kerangka untuk mengambil keputusan dengan efektif atas problem kompleks dengan menyederhanakan dan mempercepat proses pengambilan keputusan dengan menguraikan persoalan tersebut kedalam bagian-bagiannya, menata bagian atau variabel ini dalam suatu susunan hirarki (Alamsyah, 2014).

Menurut (Aziz, 2010) AHP merupakan metode yang dioperasikan untuk memecahkan masalah yang rumit dan tidak terstruktur ke dalam kelompok-kelompoknya, dengan mengelola kelompok tersebut kedalam suatu pohon hirarki, selanjutnya memasukkan nilai numerik sebagai substitusi persepsi manusia dalam melakukan perbandingan relatif. Dengan suatu sintesis maka akan dapat ditentukan elemen mana yang mempunyai prioritas tertinggi. Penyusunan hirarki dan penilaian

Tabel 1. Matriks Internal Factor Evaluation (IFE) padi organik Lampung Tengah tahun 2019

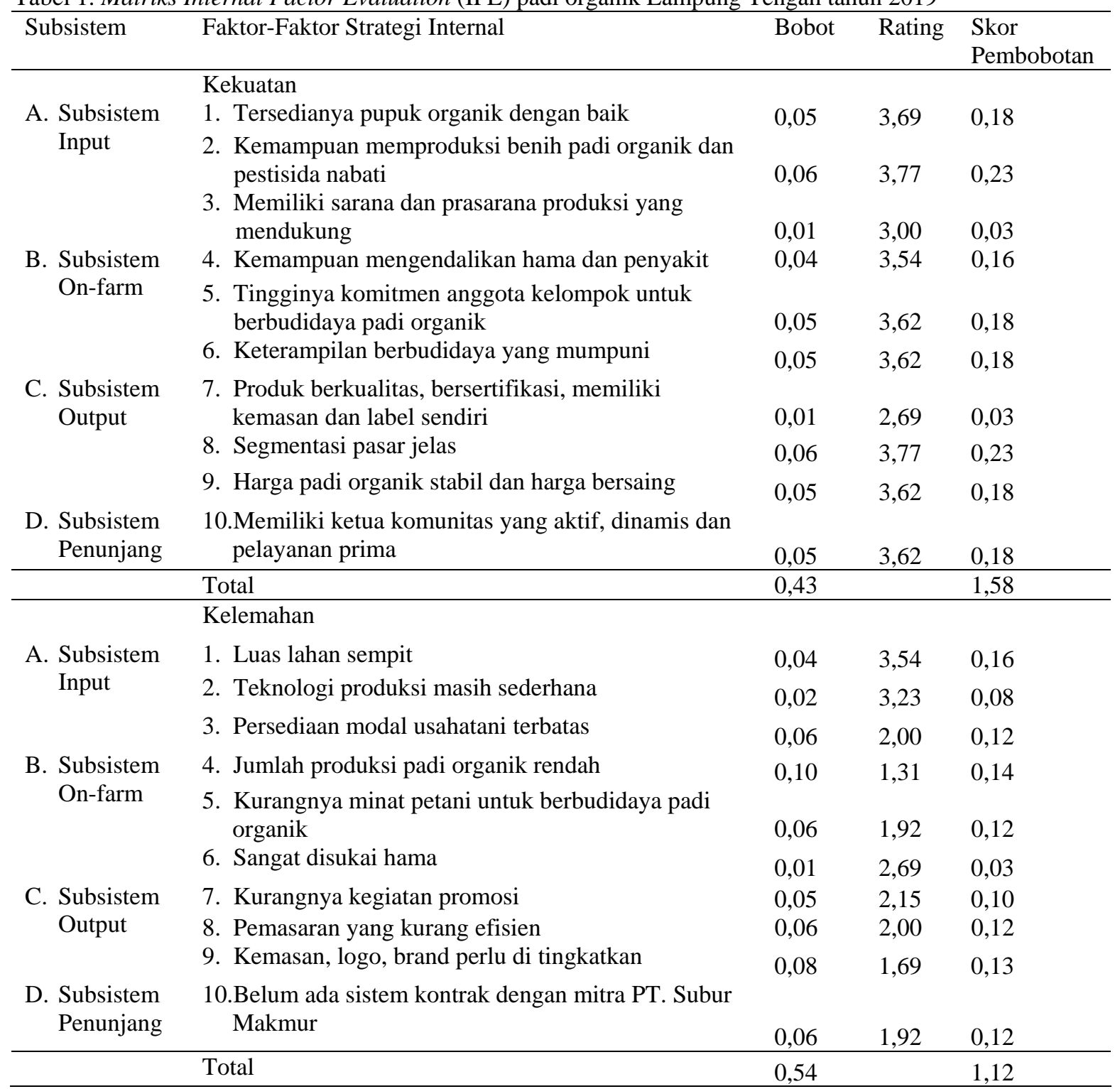

Sumber: Data Primer Diolah, 2019 
level dimulai dari permasalahan yang kompleks yang diuraikan menjadi unsur pokok, unsur pokok ini diuraikan lagi ke dalam bagianbagiannya lagi secara hirarki. Susunan hirarkinya terdiri dari goal, faktor, aktor, tujuan dan alternatif.

Kedua, proses penentuan prioritas untuk setiap level hirarki, perlu dilakukan perbandingan berpasangan (pairwise comparisons). Proses perbandingan berpasangan dimulai pada puncak hirarki (goal) digunakan untuk melakukan pembandingan yang pertama lalu dari level tepat dibawahnya (kriteria), ambil unsur-unsur yang akan dibandingkan. Ketiga menghitung bobot dari masing-masing variabel pada setiap level (alternatif) yaitu bobot setiap strategi dibandingkan dengan masing-masing sub kriteria. Nilai keseluruhan dari strategi yaitu jumlah keseluruhan dari perkalian bobot faktor dengan bobot aktor. Strategi yang dipilih adalah strategi yang memiliki nilai tertinggi.

\section{HASIL DAN PEMBAHASAN}

Faktor internal dalam sistem agribisnis padi organik dapat dijelaskan menggunakan tabel matriks IFE, dimana kekuatan dan kelemahan memiliki bobot rating yang berbeda-beda. Subsistem input, onfarm, output dan penunjang memiliki peran yang saling terkait dalam faktor internal. Tingkat bobot dan rating dapat dilihat dalam Tabel 1.

Berdasarkan Tabel 1 dapat dilihat bahwa dalam menentukan faktor internal dan faktor eksternal untuk strategi pengembangan agribisnis padi organik di Desa Astomulyo, Kecamatan Punggur menggunakan analisis IE. Analisis faktor internal dan eksternal menggunakan matriks IFE dan EFE. Hasil menunjukkan bahwa pengamatan faktor internal yang merupakan kekuatan terbesar yang paling berpengaruh terhadap pengembangan agribisnis padi organik adalah kemampuan memproduksi benih padi organik dan pestisida nabati dengan skor 0,08, dan segmentasi pasar jelas dengan skor 0,06. Hal ini menunjukkan kelompok tani memiliki keterampilan yang sangat baik dalam budidaya padi organik. Faktor internal kelemahan terbesar adalah jumlah produksi padi organik rendah dengan skor 0,10. Hal ini dikarenakan luasan lahan panen yang masih terbatas. Hasil analisis matriks untuk kekuatan mendapatkan skor 1,58 dan kelemahan mendapatkan skor 1,12. Sehingga total nilai skor adalah 2,70. Dari tabel ini menjelaskan bahwa faktor kekuatan lebih baik dari pada faktor kelemahan dalam pengembangan agribisnis padi organik. Sejalan dengan penelitian (Ifada \& Khairun, 2016) Kekuatan tertinggi yang dimiliki oleh usahatani adalah produk yang dihasilkan bermanfaat bagi kesehatan. Hal itu telah diketahui dan disadari oleh para pelaku organik, masyarakat dan aparatur negara. Akan tetapi tingkat kesadaran yang tinggi akan manfaat kesehatan dari produk tersebut membuat tingginya konsumsi beras organik.

Faktor eksternal dalam sistem agribisnis padi organik dapat dijelaskan menggunakan tabel matriks EFE, dimana peluang dan ancaman memiliki bobot rating yang berbedabeda. Subsistem input, onfarm, output dan penunjang memiliki peran yang saling terkait dalam faktor eksternal. Tingkat bobot dan rating dapat dilihat dalam Tabel 2.

Berdasarkan Tabel 2 Pada matriks EFE dapat dilihat bahwa, faktor eksternal peluang terbesar adalah adanya loyalitas pelanggan dengan skor 0,11. Hal ini menunjukkan konsumen padi organik cenderung melakukan pembelian ulang setelah mengkonsumsi. Faktor eksternal ancaman yang paling utama adalah berubahnya komitmen anggota komunitas padi organik. Hasil untuk matriks peluang mendapatkan skor 1,51 dan ancaman 0,84. Total skor nilai eksternal adalah 2,35, berarti peluang lebih besar daripada ancaman dalam faktor eksternal. Sejalan dengan hasil penelitian Safitri et al. (2014) bahwasanya pengaruh peluang lebih besar dibandingkan dengan pengaruh ancaman pada pengembangan beras organik di Desa Lubuk Bayas. Faktor peluang eksternal yang berupa ketersediaan sarana produksi, permintaan beras organik yang meningkat, dukungan kelompok tani dan dukungan lembaga masyarakat mampu meminimalisir faktor ancaman eksternal yang menghambat pengembangan sistem agribisnis beras organik di Desa Lubuk Bayas.

Berdasarkan hasil evaluasi faktor internal dan eksternal diperoleh total nilai skor faktor evaluasi internal (IFE) sebesar 2,70 dan faktor evaluasi eksternal (EFE) sebesar 2,35.

Hasil total skor digabungkan dengan menempatkan total skor IFE pada sumbu X dan 
Andika, A., Amri, K., Zulkarnain : Strategi Pengembangan Agribisnis Padi ...

Tabel 2. Matriks External Factor Evaluation (EFE) padi organik Lampung Tengah tahun 2019

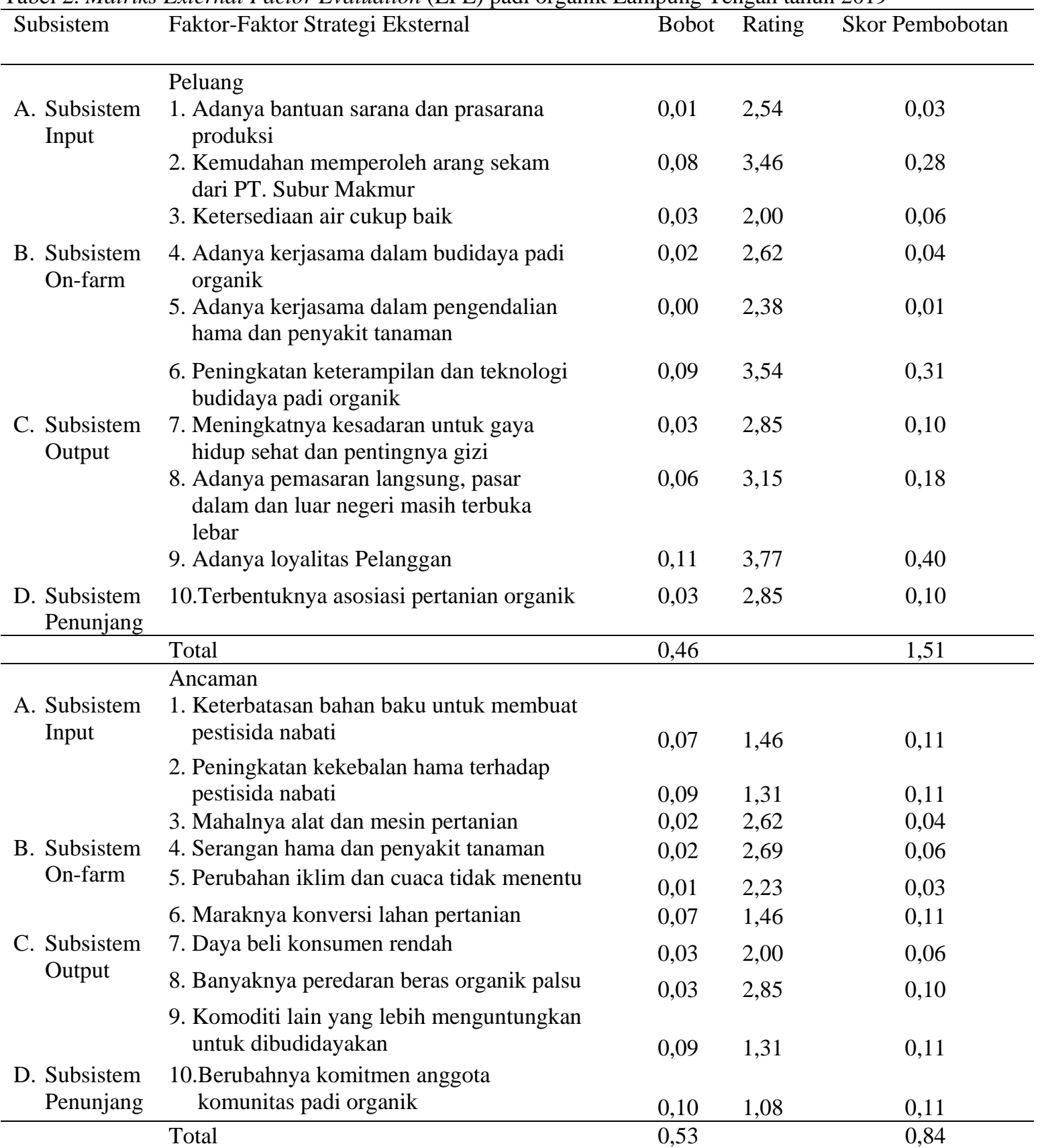

Sumber: Data Primer Diolah, 2019

total skor EFE pada sumbu Y, sehingga posisi perusahaan berada pada sel $\mathrm{V}$ seperti yang terlihat pada Gambar 1.

Gambar 1 menunjukkan bahwa nilai skor hasil matriks IE menempatkan posisi usaha petani padi organik di Komunitas Petani Organik Astorahayu, berada pada kuadran V yang merupakan posisi pertahankan dan pelihara (hold and maintain). Pada posisi ini strategi yang dapat dilakukan adalah penetrasi pasar (market penetration) dan pengembangan produk (product development). Berikut ini penjelasan strategi penetrasi pasar (market penetration) dan strategi pengembangan produk (product development) (David, 2006).

Strategi penetrasi pasar mengupayakan peningkatan pangsa pasar produk saat ini dengan upaya pemasaran yang lebih besar dan lebih luas dari sebelumnya. Penetrasi pasar mencakup meningkatkan jumlah tenaga penjual, menawarkan promosi iklan dengan 
cara ekstensif atau meningkatkan upaya publisitas secara sinergis dan berkelanjutan.

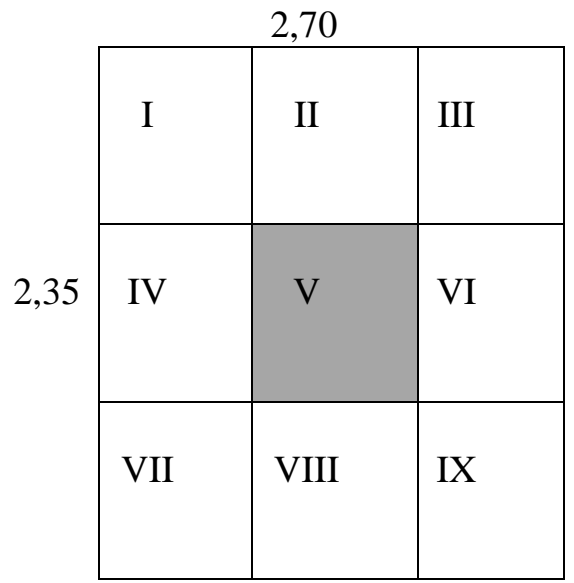

Gambar 1. Matriks IE padi organik Lampung Tengah tahun 2019

Sumber: Data Primer Diolah, 2019

Strategi pengembangan produk merupakan peningkatan penjualan dengan cara meningkatkan dan memodifikasi produkproduk yang ada saat ini. Cara yang tepat untuk melakukan strategi ini adalah melakukan sebuah riset dan pengembangan managemen.

Hasil penghubungan perhitungan pembobotan rating IFE dan EFE dapat dilihat pada Tabel 3.

Tabel 3. Pembobotan rating IFE dan EFE padi organik Lampung Tengah tahun 2019

\begin{tabular}{llll}
\hline & & $\mathrm{S}=1.58$ & $\mathrm{~W}=1.12$ \\
\hline $\mathrm{O}=1.51$ & $\mathrm{SO}=3.09$ & $\mathrm{WO}=2.63$ \\
$\mathrm{~T}=0.82$ & $\mathrm{ST}=2.40$ & $\mathrm{WT}=1.94$ \\
\hline
\end{tabular}

Sumber: Data Primer Diolah, 2019

Tabel 3 menunjukkan nilai-nilai hasil kombinasi yang telah didapatkan dari hasil penjumlahan. Bahwa nilai tertinggi adalah SO yaitu 3,09. Kemudian disusun prioritas strategi berdasarkan kombinasi strategi yang paling tinggi sampai dengan paling rendah. Dalam penelitian (Andriansyah, 2019) menyebutkan bahwa interaksi matriks IFE dan EFE menghasilkan bobot strategi StrenghOpportunity (SO) dengan skor bobot tertinggi. Bobot kekuatan lebih besar dari pada kelemahan, sedangkan bobot peluang lebih besar dari pada ancamannya, sehingga prioritas strategi yang lebih diutamakan adalah SO.
Pembobotan rating IFE dan EFE dapat dilihat pada Gambar 2.

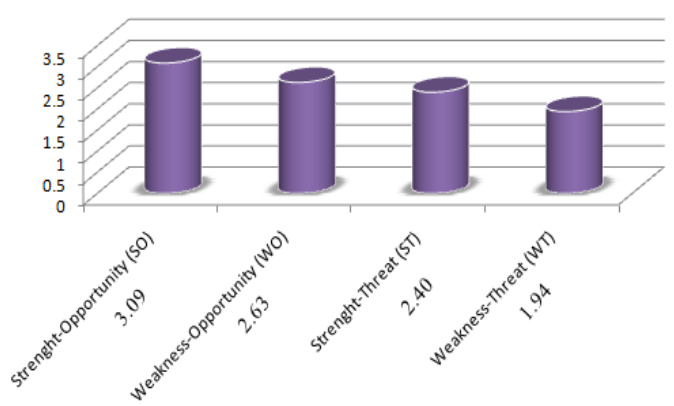

Gambar 2. Tingkat Prioritas Strategi SWOT padi organik Lampung Tengah tahun 2019 Sumber: Data Primer Diolah, 2019

Gambar 2 menunjukkan bahwa interaksi matriks IFE dan EFE menghasilkan pembobotan skor internal dan eksternal, untuk menentukan posisi strategis. Srategi Strenght Opportunity (SO) dengan skor bobot tertinggi sebesar 3,09. Strategi untuk pengembangan padi organik, bobot kekuatan lebih besar daripada kelemahan, sedangkan bobot peluang lebih besar daripada ancamannya dalam pengembangan padi organik pada Komunitas Petani Organik Astorahayu, Desa Astomulyo, Kecamatan Punggur. Kemudian diperoleh 12 strategi dalam matriks SWOT, yaitu: 1) meningkatkan keterampilan budidaya padi organik dengan memanfaatkan kerjasama anggota komunitas petani organik guna meningkatkan produktifitas, 2) menciptakan dan memperluas jaringan pemasaran, meningkatkan kinerja ketua komunitas dan anggota, guna meningkatkan distribusi beras organik, dengan memanfaatkan asosiasi dan pemasaran langsung untuk memenuhi permintaan gaya hidup sehat, 3) menciptakan kemasan dan label produk beras organik yang unik dan menarik, demi daya simpan dan menjaga loyalitas konsumen, sehingga mampu menjadi supplier beras organic dalam dan luar negeri, 4) melakukan perluasan lahan, menarik minat petani, untuk meningkatkan produksi padi organik dan memenuhi permintaan pasar dengan memanfaatkan kerjasama antar seluruh elemen yang terkait, 5) memanfaatkan kerjasama dengan PT. Subur Makmur, Asosiasi dan dengan dinas pertanian untuk mendapatkan modal dan melakukan promosi intensif demi mencapai peningkatan penjualan dan efisiensi 
pemasaran beras organik, 6) memperbarui teknologi produksi dan teknologi pasca panen untuk meningkatkan kualitas, kuantitas dan kontinuitas produk beras organik pada komunitas Kompor Astorahayu, 7) melakukan perencanaan, pengorganisasian, pelaksanaan dan pengawasan terpadu yang baik (POAC) terhadap ketersediaan pupuk, pestisida nabati, pola budidaya, pengendalian hama penyakit, hingga pada proses panen dan pasca panen, 8) menciptakan inovasi produk, menjaga stabilitas harga 3 elemen (petani, agen, pedagang) serta daya saing produk beras organik guna meningkatkan daya beli konsumen, 9) menciptakan mutu produk yang unggul dan sertifikasi resmi, 10) melakukan ekstensifikasi dan intensifikasi lahan padi organik, membangun sistem dan kerjasama dengan berbagai pihak guna menghindari maraknya konversi lahan pertanian dan mencegah perubahan komitmen anggota, 11) menciptakan edukasi dan promosi beras organik secara massif, agar konsumen terhindar dari beras organik palsu, 12) melakukan budidaya tanaman sebagai bahan baku pestisida nabati untuk menghindari kekurangan bahan baku, dan menjalin kemitraan untuk mendukung permodalan.

Dalam pengolahan AHP, proses penyusunan hirarki terdiri dari tiga (3) tahapan, yaitu: 1) mengidentifikasikan tujuan keseluruhan pembuatan hirarki atau biasa disebut goal/fokus, 2) menentukan kriteriakriteria yang dibutuhkan atau yang sesuai dengan goal/fokus keseluruhan tersebut, 3) mengidentifikasikan alternatif-alternatif yang akan dievaluasi di bawah sub kriteria (Permadi, 1992). Struktur strategi pengembangan agribisnis padi organik disusun menjadi lima 5 level hirarki. Penyusunan tersebut didasarkan pada hasil analisis SWOT, yaitu hasil nilai pembobotan yang paling tinggi dan perwakilan dari pengembangan padi organik. Struktur AHP dapat dilihat pada Gambar 3.

Gambar 3 menjelaskan level-level kriteria dalam struktur hirarki strategi pengembangan agribisnis padi organik terdiri dari: 1) Level pertama dijadikan sebagai goal/fokus yang akan dikonsentrasikan, yaitu pengembangan padi organik pada Komunitas

STRUKTUR ANALISIS HIRARKI PROSES (AHP)

STRATEGI PENGEMBANGAN PADI ORGANIK PADA KOMUNITAS PETANI ORGANIK ASTORAHAYU, DESA ASTOMULYO, KECAMATAN PUNGGUR LAMPUNG TENGAH

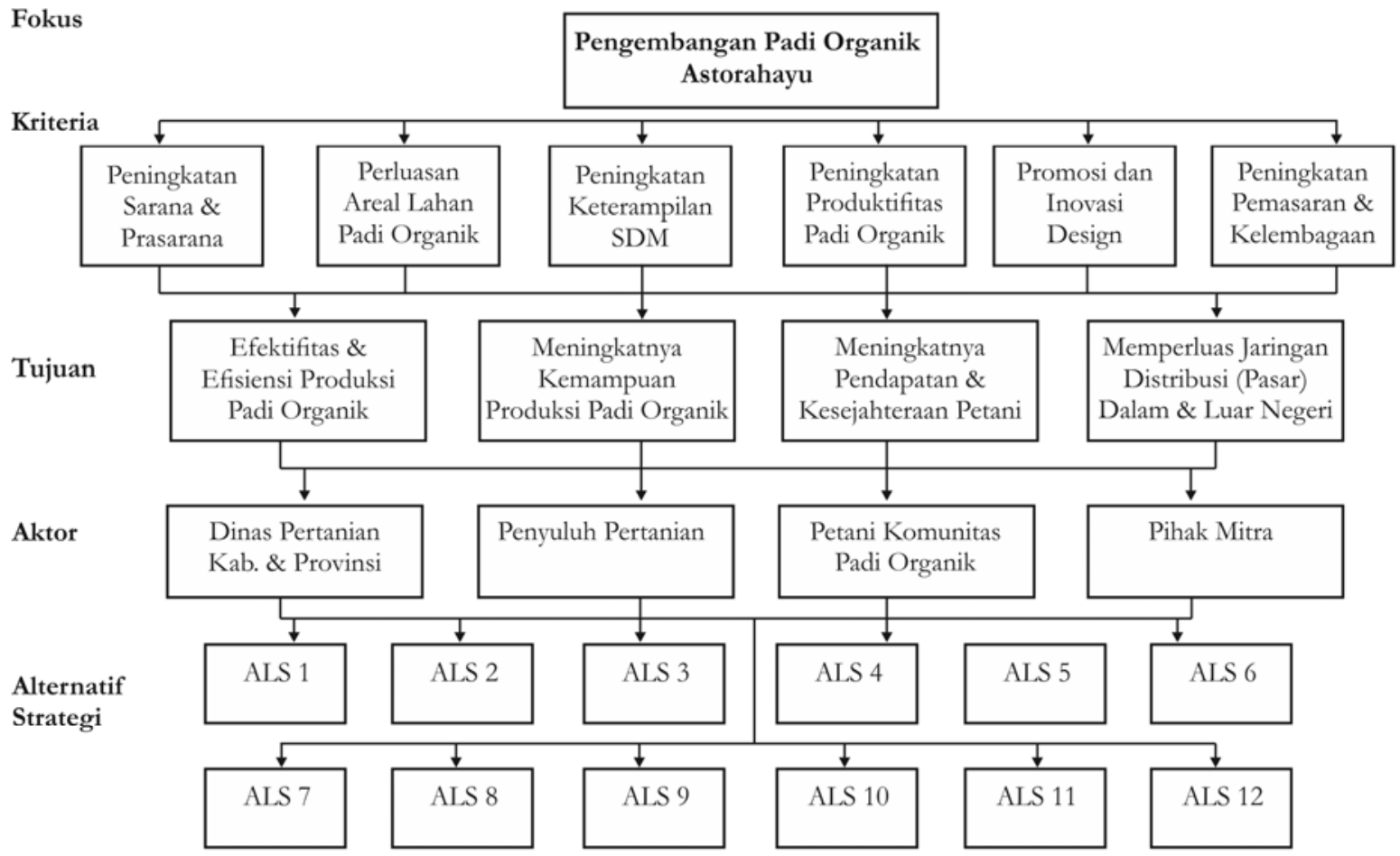

Gambar 3. Struktur AHP strategi pengembangan agribisnis padi organik Lampung Tengah Sumber: Data Primer Diolah, 2019 
Petani Organik Astorahayu, 2) Level kedua ditetapkan sebagai kriteria yang terdiri dari 6 hal penting bagi pengembangan padi organik, yaitu peningkatan sarana dan prasarana, perluasan areal lahan padi organik, peningkatan keterampilan SDM, peningkatan produktifitas padi organik, promosi dan inovasi desain produk, serta peningkatan pemasaran dan kelembagaan, 3) Level ketiga ditetapkan sebagai tujuan dari kriteria yang telah ditetapkan yaitu, efektifitas dan efisiensi produksi padi organik, meningkatnya kemampuan produksi padi organik, meningkatnya pendapatan dan kesejahteraan petani, serta memperluas jaringan distribusi (pasar) baik dalam maupun luar negeri, 4) Level keempat ditetapkan sebagai aktor yang terdiri 4 aktor yang terlibat dalam upaya pengembangan padi organik pada Komunitas Petani Organik Astorahayu, yaitu Dinas Pertanian Kabupaten dan Provinsi, Penyuluh Pertanian, Petani Komunitas Padi Organik dan Pihak Mitra, 5) Level kelima ditetapkan sebagai alternatif strategi yang dapat diterapkan dalam mencapai goal/fokus, yang terdiri dari dua belas (12) strategi.

Dilihat pada Gambar 4 menunjukkan hasil perbandingan dan pembobotan setiap level dalam struktur Analisis Hirarki Proses (AHP), diperoleh hasil sebagaimana disajikan oleh Gambar 4.

Berdasarkan Gambar 4 dapat dilihat bahwa kriteria peningkatan pemasaran dan kelembagaan menjadi prioritas utama karena dalam pengembangan padi organik pada Komunitas Petani Organik Astorahayu masih memiliki potensi dan peluang pasar yang sangat besar. Permintaan akan beras organik semakin meningkat dan konsumen yang mengkonsumsi beras organik memiliki loyalitas yang tinggi.

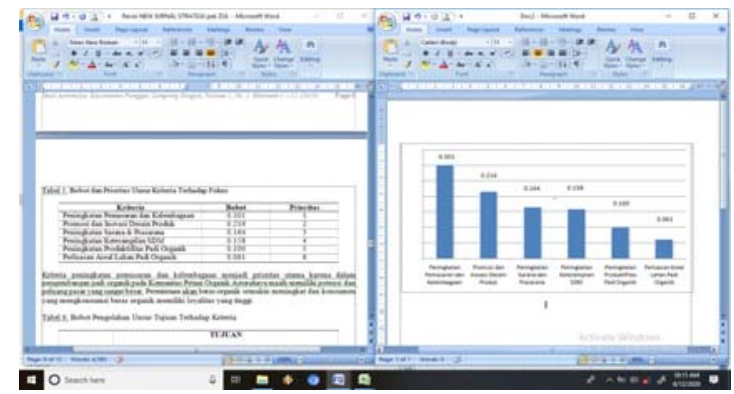

Gambar 4. Bobot dan prioritas unsur kriteria terhadap fokus padi organik Lampung Tengah Sumber: Data Primer Diolah, 2019

Untuk mengetahui dampak yang paling berpengaruh pada setiap kriteria dan tujuan, perlu dilakukan pembobotan untuk memperoleh besaran nilainya. Adapun bobot pengolahan unsur tujuan terhadap kriteria dapat dilihat pada Tabel 4.

Berdasarkan Tabel 4 dapat dilihat bahwa tujuan atau dampak yang paling berpengaruh pada dari peningkatan sarana dan prasarana adalah efektifitas dan efisiensi produksi padi organik (0,328). Tujuan yang paling berpengaruh dari perluasan areal lahan padi

Tabel 4. Bobot pengolahan unsur tujuan terhadap kriteria padi organik Lampung Tengah tahun 2019

\begin{tabular}{|c|c|c|c|c|}
\hline & TUJUAN & & & \\
\hline KRITERIA & $\begin{array}{ll}\text { Efektifitas dan } \\
\text { Efisiensi } \\
\text { Produksi PO } \\
\end{array}$ & $\begin{array}{l}\text { Meningkatnya } \\
\text { kemampuan } \\
\text { produksi PO }\end{array}$ & $\begin{array}{l}\text { Meningkatnya } \\
\text { pendapatan \& } \\
\text { Kesejahteraan }\end{array}$ & $\begin{array}{l}\text { Memperluas } \\
\text { jaringan } \\
\text { distribusi (pasar) }\end{array}$ \\
\hline $\begin{array}{l}\text { Peningkatan Sarana \& } \\
\text { Prasarana }\end{array}$ & 0,328 & 0,239 & 0,224 & 0,209 \\
\hline $\begin{array}{l}\text { Perluasan Arel Lahan } \\
\text { Padi Organik }\end{array}$ & 0,181 & 0,508 & 0,231 & 0,080 \\
\hline $\begin{array}{l}\text { Peningkatan } \\
\text { Keterampilan SDM }\end{array}$ & 0,306 & 0,376 & 0,189 & 0,129 \\
\hline $\begin{array}{l}\text { Peningkatan } \\
\text { Produktifitas Padi } \\
\text { Organik }\end{array}$ & 0,162 & 0,349 & 0,318 & 0,172 \\
\hline $\begin{array}{l}\text { Promosi dan Inovasi } \\
\text { Desain Produk }\end{array}$ & 0,105 & 0,077 & 0,368 & 0,450 \\
\hline $\begin{array}{l}\text { Peningkatan Pemasaran } \\
\text { \& Kelembagaan }\end{array}$ & 0,096 & 0,082 & 0,463 & 0,359 \\
\hline
\end{tabular}

Sumber: Data Primer Diolah, 2019 
Andika, A., Amri, K., Zulkarnain : Strategi Pengembangan Agribisnis Padi ...

Tabel 5. Bobot pengolahan unsur aktor terhadap tujuan padi organik Lampung Tengah tahun 2019

\begin{tabular}{lllll}
\hline & AKTOR & & & \\
\hline TUJUAN & $\begin{array}{l}\text { Dinas Pertanian } \\
\text { Kabupaten dan } \\
\text { Provinsi }\end{array}$ & $\begin{array}{l}\text { Penyuluh } \\
\text { Pertanian }\end{array}$ & $\begin{array}{l}\text { Petani } \\
\text { Komunitas }\end{array}$ & $\begin{array}{c}\text { Pihak } \\
\text { Mitra }\end{array}$ \\
& 0,195 & 0,275 & $\mathbf{0 , 3 7 2}$ & 0,158 \\
Efektifitas dan Efisiensi Padi Organik & 0,156 & 0,336 & $\mathbf{0 , 4 3 5}$ & 0,073 \\
Meningkatnya Kemampuan Produksi Padi & 0,200 & 0,210 & $\mathbf{0 , 4 0 8}$ & 0,182 \\
$\begin{array}{l}\text { Meningkatnya Pendapatan dan Kesejahteraan } \\
\text { Petani }\end{array}$ & & & & 0,183 \\
$\begin{array}{l}\text { Memperluas Jaringan Distribusi (pasar) Dalam \& } \\
\text { Luar Negeri }\end{array}$ & $\mathbf{0 , 4 2 5}$ & 0,076 & 0,315 & 0,15 \\
\hline
\end{tabular}

Sumber: Data Primer Diolah, 2019

Tabel 6. Bobot pengolahan unsur strategi terhadap aktor padi organik Lampung Tengah tahun 2019

\begin{tabular}{lllllllllllll}
\hline \multicolumn{1}{c}{ ALTERNATIF STRATEGI (ALS) } \\
\hline A & S1 & S2 & S3 & S4 & S5 & S6 & S7 & S8 & S9 & S10 & S11 & S12 \\
\hline D & 0,160 & 0,068 & 0,096 & 0,066 & 0,066 & 0,112 & 0,057 & 0,079 & 0,114 & 0,051 & 0,098 & 0,033 \\
PP & 0,183 & 0,080 & 0,097 & 0,069 & 0,061 & 0,101 & 0,058 & 0,063 & 0,080 & 0,069 & 0,084 & 0,053 \\
PK & 0,057 & 0,170 & 0,167 & 0,075 & 0,070 & 0,129 & 0,058 & 0,054 & 0,064 & 0,042 & 0,066 & 0,047 \\
PM & 0,065 & 0,052 & 0,173 & 0,028 & 0,143 & 0,133 & 0,041 & 0,062 & 0,094 & 0,107 & 0,055 & 0,048 \\
\hline
\end{tabular}

Sumber: Data Primer Diolah, 2019

Keterangan :

$\begin{array}{lll}\mathrm{A} & = & \text { Aktor } \\ \mathrm{S} & = & \text { Strategi } \\ \mathrm{D} & = & \text { Dinas Pertanian Kabupaten dan Provinsi } \\ \mathrm{PP} & = & \text { Penyuluh Pertanian } \\ \mathrm{PK} & = & \text { Petani Komunitas Padi Organik Astorahayu } \\ \mathrm{PM} & = & \text { Pihak Mitra }\end{array}$

organik adalah meningkatnya kemampuan produksi padi organik dengan bobot nilai $(0,508)$. Tujuan yang paling berpengaruh dari kriteria peningkatan produktifitas padi organik adalah meningkatnya kemampuan produksi $(0,349)$. Tujuan yang paling berpengaruh terhadap kriteria promosi dan inovasi desain produk adalah memperluas jaringan distribusi (pasar) dalam dan luar negeri dengan bobot nilai $(0,450)$. Tujuan yang paling berpengaruh terhadap kriteria peningkatan pemasaran dan kelembagaan adalah meningkatnya pendapatan dan kesejahteraan petani padi organik dengan bobot nilai $(0,463)$.

Untuk dapat mengetahui peran aktor yang paling tepat dalam rangka pencapaian tujuan adalah dengan melakukan perbandingan antar unsur. Bobot pengolahan unsur aktor terhadap tujuan dapat dilihat pada Tabel 5.

Berdasarkan Tabel 5 dapat dilihat hasil pengolahan horisontal antar unsur tujuan terhadap aktor yaitu aktor yang paling berpengaruh untuk dapat mencapai tujuan efektifitas dan efisiensi padi organik adalah petani komunitas padi organik itu sendiri dengan nilai $(0,372)$. Aktor yang paling berpengaruh untuk mencapai tujuan meningkatnya kemampuan produksi padi organik adalah petani komunitas padi organik, dengan nilai $(0,435)$. Aktor yang paling berpengaruh terhadap tujuan meningkatnya pendapatan dan kesejahteraan petani adalah petani komunitas padi organik itu sendiri $(0,408)$. Aktor yang paling berpengaruh terhadap tujuan memperluas jaringan distribusi (pasar) dalam dan luar negeri adalah dinas pertanian kabupaten dan provinsi $(0,425)$. Karena dinas pertanian kabupaten dan provinsi memiliki kebijakan terhadap kepentingan di dunia pertanian. Selain itu jaringan yang dimiliki oleh dinas dapat dikatakan cukup luas, sehingga mampu untuk mendukung tercapainya tujuan jaringan pemasaran yang luas, yakni di dalam hingga ke luar negeri.

Pemilihan strategi terbaik untuk dilakukan oleh aktor yang tepat akan mempercepat pengembangan padi organik. Untuk dapat memilih strategi terbaik, diperlukan pembobotan antar strategi dan aktor. Bobot pengolahan unsur strategi terhadap aktor dapat dilihat pada Tabel 6. 
Berdasarkan Tabel 6 alternatif strategi yang paling tepat untuk dilaksanakan oleh dinas pertanian kabupaten dan provinsi, dengan nilai tertinggi adalah nomor satu dengan bobot nilai $(0,160)$. Alternatif strategi dengan prioritas tertinggi untuk diterapkan, yang dapat dilaksanakan oleh aktor penyuluh pertanian adalah strategi nomor satu, dengan bobot nilai $(0,183)$. Alternatif strategi dengan prioritas tertinggi untuk diterapkan, yang dapat dilaksanakan oleh aktor petani komunitas padi organik Astorahayu adalah nomor dua, dengan bobot nilai $(0,170)$. Alternatif strategi dengan prioritas tertinggi untuk diterapkan, yang dapat dilaksanakan oleh aktor pihak mitra adalah nomor tiga, dengan bobot nilai $(0,173)$.

\section{KESIMPULAN}

Berdasarkan analisis SWOT posisi usaha petani padi organik di Komunitas Petani Organik Astorahayu, berada pada kuadran $\mathrm{V}$ yang merupakan posisi pertahankan dan pelihara. Strategi yang dapat dilakukan adalah penetrasi pasar dan pengembangan produk. Berdasarkan analisis AHP, dapat disimpulkan bahwa strategi terbaik dalam pengembangan padi organik adalah: meningkatkan keterampilan budidaya padi organik dengan memanfaatkan kerjasama anggota komunitas petani organik guna meningkatkan produktifitas. Strategi terbaik kedua adalah menciptakan kemasan dan label produk beras organik yang unik dan menarik, demi daya simpan dan menjaga loyalitas konsumen, sehingga mampu menjadi supplier beras organik dalam dan luar negeri. Dan strategi terbaik ketiga adalah menciptakan dan memperluas jaringan pemasaran, meningkatkan kinerja ketua komunitas dan anggota, guna meningkatkan distribusi beras organik, dengan memanfaatkan asosiasi dan pemasaran langsung untuk memenuhi permintaan gaya hidup sehat.

Kriteria terbaik yang dapat mendorong pengembangan padi organik adalah peningkatan pemasaran dan kelembagaan. Kriteria terbaik kedua adalah promosi dan inovasi desain produk. Sedangkan kriteria terbaik ketiga adalah peningkatan sarana dan prasarana. Aktor terbaik yang paling memungkinkan untuk dapat mengembangkan padi organik adalah petani komunitas padi organik. Aktor terbaik kedua adalah Dinas
Pertanian Kabupaten Lampung Tengah dan Dinas Pertanian Provinsi Lampung. Sedangkan aktor terbaik ketiga adalah penyuluh pertanian. Tujuan terbaik dalam pengembangan padi organik adalah meningkatkan kemampuan produksi padi organik. Tujuan kedua adalah meningkatkan pendapatan dan kesejahteraan petani padi organik. Dan tujuan ketiga adalah memperluas jaringan distribusi (pasar).

\section{UCAPAN TERIMA KASIH}

Ucapan terima kasih dan penghargaan disampaikan kepada Perhiptani Provinsi Lampung, Dinas Pertanian Tanaman Pangan dan Hortikultura Provinsi Lampung, Dinas Pertanian Tanaman Pangan dan Hortikultura Kabupaten Lampung Tengah, Balai Penyuluhan Pertanian, Perikanan dan Kehutanan (BP3K) Kecamatan Punggur, serta Komunitas Petani Padi Organik Astorahayu.

\section{DAFTAR PUSTAKA}

Alamsyah, D. P. (2014). Metode Analytical Hierarchy Process: Sistem rekomender database software. Jurnal Informatika, 1 (2), 1-15.

Aminah, M. (2017). Strategi pengembangan usaha padi organik bersertifikat berkelanjutan di Kabupaten Tasikmalaya [Disertasi]. IPB, Bogor.

Andriansyah, A. (2019). Analisis strategi pengembangan tanaman hias (Floriculture) di Desa Siraman Kecamatan Pekalongan Kabupaten Lampung Timur [Skripsi]. STIPER Dharma Wacana, Metro.

Aziz, I. J. (2010). Pembangunan Berkelanjutan: Peran dan Kontribusi Emil Salim. Jakarta: Gramedia Pustaka Utama.

Balitbangtan. (2010). Peta Potensi Penghematan Pupuk Anorganik dan Pengembangan Pupuk Organik pada Lahan Sawah Indonesia. Jakarta: Badan Penelitian dan Pengembangan Pertanian. 
David, F. R. (2006). Manajemen Strategis Konsep. Edisi Sepuluh. Jakarta: Salemba Empat.

Ifada, I. I., \& K. N. (2016). Faktor eksternal dan internal dalam upaya pengembangan agribisnis padi organik. Al Ulum Sains dan Teknologi, 2(1), 1-5.

Jamison, R. J., \& Perkins, J. H. (2010). The History of Organic Agriculture. in: Rosemeyer M, Gliessman SR, Editor. The Conversion to Sustainable Agriculture; Principle, Process and Practices. New York: CRS Press Taylor \& Francis Group.

Jumna, B. K. (2015). Strategi pengembangan usahatani dalam upaya peningkatan produksi padi organik. Economics Development Analysis Journal (EDAJ), 4(2), 233-241.

Lestari, A. P. (2009). Pengembangan pertanian berkelanjutan melalui substitusi pupuk anorganik dengan pupuk organik. Jurnal Agronomi, 13(1), 38-44.
Permadi, B., \& Brojonegoro, B. (1992). AHP Pusat Antar Universitas, Studi Ekonomi. Jakarta: UI.

Rai, N. (2018). Dasar-Dasar Agronomi. Denpasar: Pelawa Sari.

Research Institute of Organik Agriculture (FIBL). (2018). International Federation of Organic Agricultural Movement. Frick, Switzerland: FIBL.

Saaty, T. L. (1993). Pengambilan Keputusan Bagi Para Pemimpin, Proses Hirarki Analitik Untuk Pengambilan Keputusan dalam Situasi Yang Kompleks. Jakarta: PT Pusaka Binaman Pressindo.

Safitri, S. A., Chalil, D., \& Emalisa. (2014). Strategi pengembangan sistem agribisnis beras organik. Journal of Agriculture and Agribusiness Socioeconomics, 2(10), $1-15$.

Sucihatiningsih, D. \& Waridin. (2010). Model penguatan kapasitas kelembagaan penyuluh pertanian dalam meningkatkan kinerja usahatani melalui transaction cost. Jurnal Ekonomi Pembangunan, 11(1), 13-29. 